\title{
Review
}

\section{Apoptosis without caspases: an inefficient molecular guillotine?}

\author{
Christoph Borner*,1 and Laurent Monney ${ }^{1,2}$ \\ 1 Institute of Biochemistry, University of Fribourg, Rue du Musée 5, CH-1700 \\ Fribourg, Switzerland \\ ${ }^{2}$ Current address: Center for Neurologic Diseases, Brigham and Women's \\ Hospital, Harvard Medical School, Boston, MA 02115, USA \\ * corresponding author: Christoph Borner, Institute of Biochemistry, University \\ of Fribourg, Rue du Musée 5, CH-1700 Fribourg, Switzerland. \\ tel: ++41 2630086 54; fax: ++412630097 35; \\ e-mail: christoph.borner@unifr.ch
}

Received 22.02.99; accepted 23.03.99

Edited by M. Piacentini

\begin{abstract}
Since the discovery that the cysteine protease CED-3 was essential for developmental death in the nematode C. elegans, the search has been on to identify homologous proteases governing mammalian apoptosis. Fourteen of these proteases, now called caspases, have been found to date, and studies with natural or chemical inhibitors, and more recently knock-out mice, confirmed the involvement of at least a subset of these proteases in various forms of mammalian apoptosis. However, there has been recent evidence that some apoptotic morphologies, such as cell shrinkage, membrane blebbing and nuclear condensation, are not blocked by caspase inhibitors and that the cells continue to die in a protracted and inefficient manner. This has led to the notion that caspases are not required for all aspects of apoptosis in mammals. Here we review the current knowledge about caspase-independent apoptosis, discuss the strengths and weaknesses of the reasoning that led to its proposition and provide insights into its possible regulation and physiological significance.
\end{abstract}

Keywords: apoptosis; programmed cell death; caspase-independent; Bcl-2; Bax; mitochondria; cytochrome c; ced genes; C. elegans; Drosophila

Abbreviations: CED, cell death abnormal; rpr, reaper; hid, head involution defective; IAP, inhibitor of apoptosis protein; DFF, DNA fragmentation factor; $C A D$, caspase activated Dnase; DED, death effector domain; CARD, caspase recruiting domain; FADD, Fasassociated death domain; RAIDD, RIP-associated Ich-1/CED-3 homologous protein with a death domain; $\mathrm{TNF} \alpha$, tumor necrosis factor $\alpha$; Apaf-1, apoptotic protease activating factor 1; PT, permeability transition pore; ANT, adenine nucleotide translocator; ROS, reactive oxygen species; ER, endoplasmic reticulum; AIF, apoptosis inducing factor; NO, nitric oxide; PS, phosphatidylserine; SOD, superoxide dismutase; CAT, catalase; TEGT, testis enhanced gene transcript; BI-1, Bax inhibitor-1; TUNEL, terminal deoxynucleotidyl transferase-mediated dUTP nick-end labeling; Z-VAD.fmk, Z-Val-Ala-Asp.fluoromethylketone; BD.fmk, t-butoxy carbonyl-Asp.fluoromethylketone

\section{Apoptosis: a cell-intrinsic molecular guillotine}

In the early 1970s, Kerr, Wyllie \& Currie reported that cells undergo at least two distinct forms of death: a violent, rapid necrosis characterized by cytoplasmic swelling, membrane rupturing and organelle dissolution with relatively unremarkable nuclear changes and a more protracted, morphologically distinct apoptosis when cells shrink, dissociate from neighbors, leave their organelles mostly intact but show extensive nuclear/cellular fragmentation and expose novel surface molecules for rapid phagocytosis. ${ }^{1,2}$ Ever since, cell deaths observed in culture and tissues have been classified into the simple dichotomy, apoptosis or necrosis. Today, we however know forms of cell death that cannot be readily fitted into either category, for example when cells die by cytoplasmic and membrane changes seen in apoptosis but do not exhibit DNA and/or nuclear fragmentation (see below). Even the initial dogma that apoptosis execution absolutely requires a specific class of proteases, called caspases, is about to tumble.

Apoptosis has been first recognized during vertebrate development as part of a natural process to remove superfluous or used-up cells.,.$^{3,4}$ It has since become evident that death morphologies closely resembling ontogenic deaths occur in post-developmental cells in response to various physiological, pathological or pharmacological agents. ${ }^{5,6}$ Crucial roles of apoptotic death have thus been extended to morphogenesis, tissue homeostasis, immune regulation and the elimination of infected, mutated or damaged cells. ${ }^{5-7}$ In all these cases, an afflicted cell senses that its environment or physical state has been compromised and by consequence undergoes a suicide process, using an intrinsic molecular death machine similar to the guillotine of the French revolution (Figure 1). Because every cell in a multicellular organism may once encounter an unfavorable situation, it is conceivable to propose that all living cells contain such a death machinery. As long as the cell survives, the guillotine hangs inactively on the rope. If a cell is to be removed, some death signal stimulates a 'trigger' molecule that, with the help of an efficient tool, progressively cuts into the rope until it breaks and unleashes the guillotine onto the cell (Figure 1). This process can be stopped by 'savers' up to the point of the final, guillotine releasing cut. As there can be many 'triggers' and 'savers', many molecules can activate or 
block apoptosis via distinct intracellular signaling pathways (Figure 1). However, only one tool (for example an axe), and thus class of molecules, might be the most effective in the execution process. Does this account for all sorts of apoptosis in eukaryotic cells or can execution also be accomplished by less efficient tools, say a scissor?

\section{The efficient CED-3 execution 'axe' of nematodes}

Genetic analysis in the nematode $C$. elegans unveiled two gene products, CED-3 and CED-4, which are essential for developmental apoptosis, i.e. worms lacking either one of them or both contain at birth 131 superfluous cells. ${ }^{8,9}$ CED-3 encodes a cysteine protease, called caspase, that cleaves cellular substrates after aspartate residues. ${ }^{9}$ Although physiological substrates for CED-3 are not yet known, studies in higher eukaryotes revealed that CED-3 is probably the 'cutting axe' that progressively cleaves numerous cellular proteins until the rope of the guillotine breaks. This has been elegantly proven by showing that a general caspase inhibitor from baculovirus, called p35, blocks developmental apoptosis to the same extent as in CED-3 null worms. ${ }^{10}$ CED-3 is activated by the upstream 'trigger' CED-4. ${ }^{9}$ This protein physically interacts with CED-3 as an oligomer causing the protease to aggregate and get autoactivated. ${ }^{11-14}$

\section{Apoptosis in the fly: The same 'cutting tool', but other 'triggers'}

Widespread cell death occurs during Drosophila development and can additionally be induced by DNA damaging agents. ${ }^{15,16}$ These deaths are morphologically identical to apoptosis suggesting a similar underlying mechanism as in worms. A first genetic screen had however not immediately identified CED-3 like execution caspases but three gene products, called reaper (rpr), head involution defective (hid) and grim, that function as apoptosis triggers rather than executioners. ${ }^{16-18}$ Rewardingly, rpr, hid or grim-induced apoptosis was impeded by the co-expression of the caspase
A.

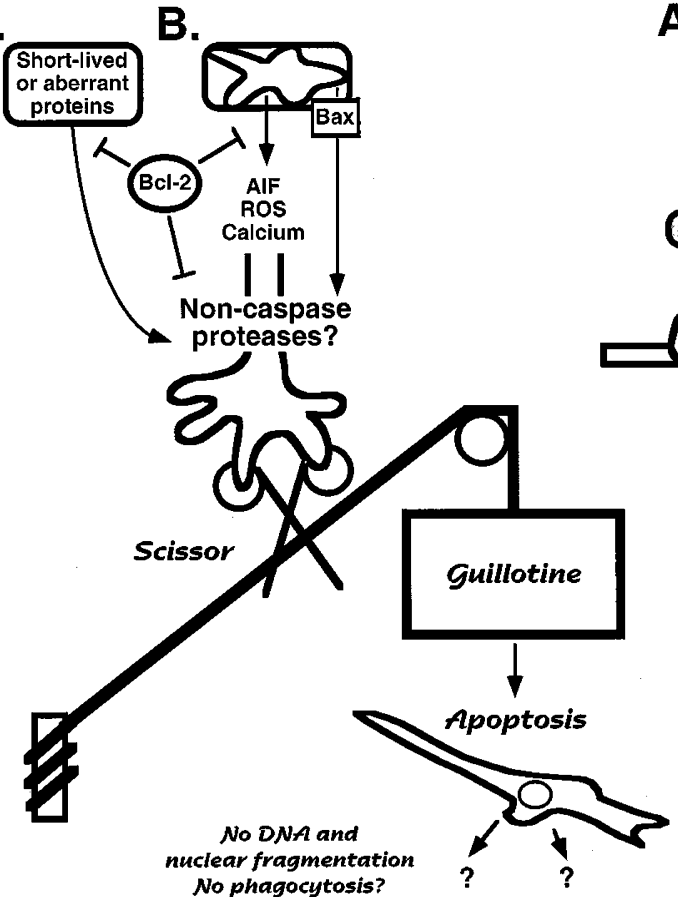

A.

B.

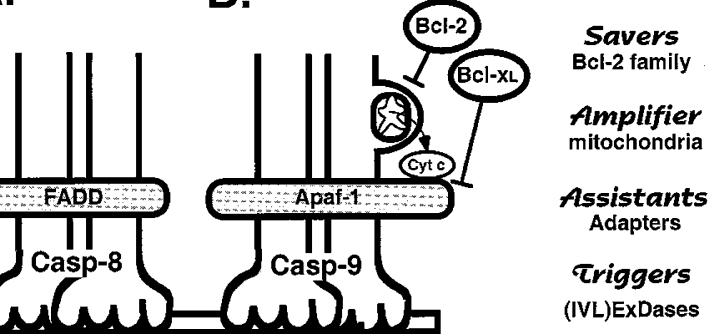

Figure 1 Caspase-dependent and -independent activation of the apoptotic 'guillotine'. Multicellular organisms primarily use caspase-dependent apoptosis (right panel) to eliminate superfluous, used-up and damaged cells. This ensures a rapid and efficient cleavage of nuclear and cellular structures as well as an immediate phagocytosis of the cell fragments. An apoptotic stimulus clusters 'assistant' molecules such as FADD to oligomerize and autoactivate 'trigger' caspases ((IVL)ExDases) which in turn launch the 'cutting axe', an efficient execution tool consisting of the DExDase caspases-3 and -7 (A). The 'axe' progressively cuts into the rope of the guillotine until the latter unleashes and fragments the cell. Execution can be amplified by triggers with strong 'muscles', i.e. mitochondrial components such as cytochrome $c$ which enhance caspase activation via the 'assistant' Apaf-1 (B). The guillotine can be prevented from falling by 'savers' which block triggers or unsharpen the axe (caspase inhibitors, not shown) or disable the 'muscle' (cytochrome $c$ release, Bcl-2) or 'assistants' (Apaf-1, Bcl- $\mathrm{x}_{\mathrm{L}}$ ). If caspases are absent (yeast, enucleated cells, caspase knock-outs) or blocked (Z-VAD.fmk, baculovirus p35) the rope of the guillotine can still be cut, but by a less efficient 'scissor' (left panel). In this case, DNA and nuclear fragmentation does usually not occur but the cell continues to die with an otherwise apoptotic morphology without being necessarily phagocytosed. Trigger molecules may be accumulating short-lived and/or damaged proteins (A) or mitochondrial components such as AIF, ROS and calcium whose release into the cytoplasm could be under the control of the Bax channel (B). The 'scissors' may be non-caspase proteases such as serine proteases, calpains or cathepsins. Bcl-2 can still save the guillotine from falling. For details, see text 
inhibitor baculovirus p35 indicating that all three gene products acted upstream of some putative Drosophila execution caspase(s). ${ }^{17-20}$ Three CED-3-like caspases, drICE, DCP-1 and DCP-2/DREDD have since been identified in the fly. ${ }^{21-23} \mathrm{DCP}-1$ is required for early stages of Drosophila development as its loss of function leads to female sterility by inhibiting transfer of cytoplasm from apoptotic nurse cells to the primary oocyte. ${ }^{24}$ Moreover zygotic loss of this caspase causes larval lethality and melanotic tumors. ${ }^{22}$ Thus, as in $C$. elegans, caspases are an effective 'cutting tool' to execute physiological apoptosis in Drosophila. Interestingly, while the 'cutting tool' has been evolutionary conserved between worms and flies, the triggers appear to be distinct. Neither has a CED-4 homolog been found in Drosophila nor any of the activators rpr, hid and grim in $C$. elegans. Moreover different strategies are used to prevent the guillotine from falling. While $C$. elegans possesses a gene product, called CED- 9 which interferes with developmental apoptosis by directly binding and neutralizing the 'preferred trigger' CED-4, ${ }^{11,12,25-28}$ no such homolog has yet been found in Drosophila. The fly instead uses Inhibitors of Apoptosis Proteins (IAPs) that either associate and interfere with the triggers $\mathrm{rpr}$, hid and grim ${ }^{29}$ or with the activated caspase axe. ${ }^{30}$

\section{The guillotine of mammals: Further complexities to trigger, prevent and execute the 'rope cutting' process}

There is no doubt that the regulation of life and death is more complex in mammals than worms and flies. More than 14 mammalian caspases have so far been identified, all of which are expressed as inactive proenzymes that are proteolytically activated to form a tetrameric catalytic complex. ${ }^{31}$ They can be divided into three major groups based on their preference for a tetrapeptide recognition sequence in their substrates (DExDases, WEHDases, (IVL)ExDases). ${ }^{32,33}$ While WEHDases function primarily as inflammatory mediators, the other two groups regulate apoptosis. At least two DExDases, caspase- 3 and caspase-7, can function as axe of the mammalian guillotine (Figure 1) because all apoptotic stimuli activate one or the other enzyme, the substrate analog inhibitor DEVD-CHO blocks most forms of apoptosis and deletion of caspase- 3 causes perinatal lethality in mice due to brain malformations. ${ }^{32-35}$ Moreover, most of the caspase substrates identified so far are cleaved after DExD sequences. ${ }^{32,36}$ Although we do not yet know which cleavages are essential for apoptosis execution, many facilitate cell disassembly ('cutting the rope until the guillotine falls'). This includes the caspase-activated nuclease DFF40/ CAD which cleaves the DNA into internucleosomal fragments, ${ }^{37,38}$ and cytoskeletal proteins such as actin, $\alpha$-fodrin, gelsolin and the nuclear lamins whose cleavages may contribute to cell shrinkage, membrane blebbing and nuclear breakdown. $^{39-42}$

If mammalian apoptosis is predominantly executed by DExDases, why is another subgroup of caspases needed? It turns out that the (IVL)ExDases are used to form a probably stimulus-specific proteolytic cascade (trigger chain) that ends up in the cleavage and activation of pro-
DExDases (Figure 1). ${ }^{31,32}$ This is because mammalian DExDases contain an $\mathrm{N}$-terminal inhibitory pro-domain that needs to be proteolytically removed for effective autoactivation. The connection between the death stimuli and the proteolytic cascades is ensured by adaptor proteins (trigger assistants). These proteins self-associate in response to an apoptotic stimulus and, by binding to a long $\mathrm{N}$-terminal pro-domain present only in 'trigger' caspases (DED or CARD domain), oligomerize and autoactivate the first protease in the cascade (Figure 1). ${ }^{31,32}$ For example, Fas/APO and other TNF $\alpha$-like molecules use the adapters FADD and RAIDD to oligomerize and autoactivate the 'trigger' pro-caspase-8 and pro-caspase-2, respectively. ${ }^{43,44}$ Caspase- 8 then directly cleaves and activates caspase-3 (Figure 1). ${ }^{45}$ The proof that (IVL)ExDases are 'trigger' caspases on selected apoptotic pathways upstream of DExDases has been obtained by inhibitor and knock-out mice studies. For example caspase-8 null animals are resistent to Fas/APO and TNF $\alpha$-induced apoptosis, ${ }^{46}$ but are still susceptible to chemotherapeutic drugs, serum withdrawal and dexamethasone. By contrast, cells deficient in caspase-9, another 'trigger' caspase, remain sensitive to killing signaling by TNF or Fas/APO but show resistance towards $\gamma$-irradiation, chemotherapeutic drugs and dexamethasone. ${ }^{47,48}$

Thus, it appears that all what the mammalian execution 'axe' requires for its activation is an upstream cascade of 'trigger' caspases with their respective 'assistants' (adapters). What is then the function of CED-4 like molecules? The only so far identified mammalian CED-4 homolog, called Apaf-1, acts as a classical assistant as it binds to pro-caspase- 9 and provokes self-association and activation of the protease (Figure 1). ${ }^{49-51}$ This function of Apaf-1 is however not restricted to specific stimuli (such as FADD on the Fas/TNF-R pathway) but part of a commonly used apoptotic signaling pathway which involves mitochondrial components. $^{52}$ Interestingly, such a pathway has not yet been found in nematodes and is probably a recent evolutionary invention. Has CED-4 been deviated to function on a mitochondria-specific apoptotic pathway in mammals?

Mitochondrial damage has been viewed as a typical sign of necrosis where the organelles swell, break open, prevent further ATP production and subsequently kill cells by disrupting ion homeostasis. Recently, significant but more subtle mitochondrial changes have also been noted during apoptosis. ${ }^{53-55}$ They include enhanced production of oxygen radicals, calcium cycling, the fall in the transmembrane potential and an increased permeability of the outer mitochondrial membrane. ${ }^{53-55}$ How these changes are triggered by apoptotic stimuli, whether they are causally linked and whether they are absolutely required for the activation of execution caspases is still a matter of large debate. What almost invariably occurs in response to various apoptotic stimuli is the release of cytochrome $c$ from the intermembrane space of mitochondria to the cytoplasm ${ }^{56-59}$ where it binds to the 'assistant' Apaf-1, leading to the sequential activation of pro-caspase- 9 and -3 (Figure 1$)^{49-52}$ How important is this pathway for apoptosis 
execution? Apaf-1 and caspase-9 knock out mice are severely compromised in brain development and die in utero. ${ }^{47,48,60,61}$ However, morphogenesis in other parts of the body, such as for example the removal of interdigital webbing, was remarkably normal (although delayed by one day in Apaf-1 null mice). Also, apoptosis in response to Fas/APO and TNF $\alpha$ was largely unaffected and although caspase-3 activation and DNA fragmentation in response to other stimuli such as $\gamma$-irradiation, dexamethasone and chemotherapeutic drugs were blocked after a certain time, they may nevertheless occur later on. ${ }^{47,48,60,61}$ Thus, the observed defects in these knock-out animals could be due to a delayed rather than abrogated apoptosis and the role of mitochondrial components would then be to amplify rather than execute the death process, as recently suggested. ${ }^{62}$ In this respect, one could view mitochondrial contribution like having a trigger with strong muscles that launches the caspase- 3 'axe' more effectively than a trigger with weak muscles (Figure 1). Such 'strong muscles' are especially important for the rapid and efficient removal of cells during embryonic development, thus explaining the brain defects in caspase- 9 and Apaf-1 null mice.

How does a mammalian cell prevent its guillotine from falling? On one hand, it expresses several IAP proteins (NAIP, X-IAP, clAPs) that either function as direct caspase inhibitors or interveners of Fas/TNF $\alpha$-activated apoptotic pathways. ${ }^{29,30,63-65}$ In addition, there are at least 16 human homologs of the nematodal CED-9 survival factor of which the proto-oncogene product $\mathrm{Bcl}-2$ is the founding member. ${ }^{66,67}$ Although $\mathrm{Bcl}-2$ can mimic the death protective effect of CED-9 in worms and vice versa, the two proteins appear to function slightly differently. ${ }^{66-68}$ While CED-9 directly binds to CED-4 and prevents the latter from activating CED-3, ${ }^{11,12,26,27} \mathrm{Bcl}-2$ does not avidly interact with the CED-4 homolog Apaf-1 (own observation) but prevents the release of cytochrome $c$ from mitochondria thereby blocking caspase-9/-3 activation upstream or independently of Apaf-1 (Figure 1). ${ }^{57,58} \mathrm{How} \mathrm{Bcl}-2$ performs this peculiar action on mitochondria has remained elusive. Perhaps it has acquired a new function to disable the 'muscle' rather than the 'assistant' of the 'trigger caspase' (Figure 1). That the original function of CED-9 has been nevertheless conserved is demonstrated by $\mathrm{Bcl}$ $\mathrm{x}_{\mathrm{L}}$, another potent anti-apoptotic member of the Bcl-2 family which, as expected, interacts with Apaf-1 and prevents Apaf-1 mediated caspase-9 activation (Figure 1). ${ }^{69,70}$ Thus, during evolution several homologues 'CED-9 savers' have been created that each seems to act on different devices (muscles, assistants, triggers) to prevent the caspase 'axe' from cutting the rope.

\section{Apoptosis without caspases: 'Pros' and 'Contras'}

If caspases are the only tool to exert the execution step of apoptosis, appropriate protease inhibitors should prevent apoptotic morphology and death and allow cells to survive in a functional state. This concept has been widely tested with the cell permeable tripeptide inhibitor Z-Val-AlaAsp.fluoromethylketone (Z-VAD.fmk). ${ }^{74}$ Due to an aspartate residue mimicking the cleavage site and a fmk group forming a covalent inhibitor/enzyme complex, the inhibitor instantly and irreversibly binds to the catalytic site of caspases. ${ }^{33,75,76}$ In addition, by replacing the caspase-specific P4 amino acid with a hydrophobic moiety $(Z)$, the peptide is capable of occupying the catalytic pocket of all caspases thus making it a broad range caspase inhibitor. Indeed, Z-VAD.fmk and the related compound t-butoxy carbonyl-Asp.fluoromethylketone (BD.fmk) proved to be effective in blocking apoptosis in different animal disease models such as stroke, myocardial ischemia/reperfusion injury, liver disease and traumatic brain injury. ${ }^{77-80}$ In both liver and ischemic brain models, the recovered cells were shown to be functional. ${ }^{77,78}$

Given these straightforward results, it came as a surprise when two years ago, McCarthy et al reported that while cells treated with Z-VAD.fmk or BD.fmk did not display cleavages of caspase substrates, chromatin condensation or nucleosomal laddering in response to oncogenic and DNA damaging apoptotic stimuli, they continued to exert other apoptotic features such as cell shrinkage and membrane blebbing for hours and could not be rescued from the death fate. ${ }^{81}$ This observation suggested that certain cytoplasmic hallmarks of apoptosis may be triggered by enzymes other than caspases, but that the nuclear events required caspase activity. Subsequent studies have lent support for such caspaseindependent phases of apoptosis. For example, ZVAD.fmk could not rescue cells from apoptosis induced by the overexpression of Bax although caspase-3 activation and nuclear fragmentation were clearly blocked. ${ }^{82,83}$ Similarly, Z-VAD.fmk inhibited nuclear damage of target cells induced by exocytotic granules of cytotoxic $\mathrm{T}$ cells but did not prevent target cell lysis (as measured by $\mathrm{Cr}^{51}$ release). ${ }^{84,85}$ More recent examples include apoptosis induced by the GD3 ganglioside, ${ }^{86}$ class I MHC antibodies, ${ }^{87}$ puromycin, ${ }^{88}$ polyamine analogues, ${ }^{89}$ CD-2 and staurosporine, ${ }^{90,91}$ intracellular acidification, $^{92}$ the retinoid AHPN, ${ }^{93}$ E4orf4, a novel adenovirus death factor, ${ }^{94}$ irradiation, ${ }^{95,96}$ VP-16, dexamethasone and actinomycin D, ${ }^{97-99} \mathrm{PML},{ }^{100}$ and nitric oxide (NO). ${ }^{101}$ Even some aspects of Fas-induced apoptosis (when triggered with the adapter FADD) may occur caspaseindependently although in this case necrotic morphologies were observed as well. ${ }^{102}$ In our own hands, we have not seen any apoptotic system in culture (using various physiological and toxic stimuli) where Z-VAD.fmk could save cells from dying. The inhibitor reproducibly blocks the activation of execution caspases and nuclear fragmentation, but nuclei have irregular shapes and are partially condensed, the ER dilates, cells still shrink and display dramatic blebbing at the surface, and no rescue and/or clonogenic growth is possible at any time after removal of the inhibitor (own observations). Why then can cells be fully rescued with Z-VAD.fmk in models of ischemia and liver damage? ${ }^{77,78}$ Either these are special cases of entirely caspase-dependent, apoptotic processes or the attenuation of damage by Z-VAD.fmk is a consequence of the inhibition of enzymes other than caspases. Alternatively, the rescue may not be as complete as thought. A recent report shows that neurons saved with Z-VAD.fmk 
after an apoptotic challenge in low $\mathrm{KCl}$ stay in a hypoenergetic state, vulnerable to necrosis. ${ }^{103}$

Is there enough evidence to propose that mammalian cells can undergo apoptosis caspase-independently? Unfortunately most of the data proposing such a form of apoptosis have been collected from experiments using the artificial caspase inhibitor Z-VAD.fmk or related agents. ${ }^{81-103}$ Although Z-VAD.fmk is known to block all so far known caspases, ${ }^{33}$ we cannot exclude that yet unidentified caspases are resistant to this drug. We also do not know whether the inhibitor is sufficiently stable inside cells. It has recently been reported that inhibitory peptides based on their substrate recognition sequence (f. ex. DEVD) are not necessarily strong inhibitors because they are rapidly degraded. ${ }^{104}$ Appropriate amino acid substitutions can convert the inhibitor into a stable compound (DQMD) that even allows clonogenic growth after removal. ${ }^{104}$ Moreover, it is worrysome that Z-VAD.fmk can inhibit other cysteine proteases such as calpain ${ }^{105}$ and cathepsin $\mathrm{B}^{106}$ because such inhibitions may provoke additional cell death. Finally, the methylketone group of Z-VAD.fmk and related peptide inhibitors is fairly reactive and covalently labels intracellular lipids and proteins (including other proteases such as cathepsin $\mathrm{H}$ and $\mathrm{B}$ ) at concentrations generally used to demonstrate the involvement of caspases $(>100 \mu \mathrm{M}) .^{106}$ This may be another source of non-specific, cytotoxic side effects. Future work has therefore to focus on repeating the Z-VAD.fmk experiments with more natural caspase inhibitors.

One such inhibitor could be baculovirus p35 as it is quite effective in blocking caspase activation and nuclear fragmentation in many cell culture and animal models of apoptosis. ${ }^{10,17-20,71-73,107}$ In some cases such as for example the degeneration of the Drosophila retina, p35 actually restored visual function to otherwise blind flies. ${ }^{107}$ Its potency might be due to the fact that it forms a stable complex with the catalytic site of the caspase after being cleaved at a DQMD sequence. ${ }^{108}$ However, only a subset of caspases $(-1,-3,-6,-7,-8$ and -10$)$ have so far been demonstrated to be inhibited by recombinant p35 in vitro, ${ }^{109}$ and there are at least three reported cases where p35 cannot rescue cells from apoptosis. ${ }^{84,101,110}$ Of course, this could be due to p35 expression levels that are too low for caspase inhibition, as many investigators have problems to highly overexpress p35 due to its viral origin. Alternatively, p35 may not block all caspases. This would explain a recent study where Z-VAD.fmk, but not p35, blocked reaper-induced ceramide production although both inhibitors similarly interfered with downstream caspase activation and nuclear fragmentation. ${ }^{111}$ Thus, to validate the existence of caspase-independent apoptosis, it will be necessary to develop and test other physiological caspase inhibitors or knock-out mice deficient in more than one execution caspase (caspases-3, -7, -6).

\section{Execution of caspase-independent apoptosis: Scissor instead of axe?}

If caspase-independent apoptosis indeed exists what cellular components might be involved? In most apoptotic systems Z-
VAD.fmk does not block mitochondrial changes such as the fall of the membrane potential, the production of oxygen radicals or the release of apoptogenic factors like cytochrome $\mathrm{c}$ and apoptosis-inducing factor (AIF). 53,54,82,90,94,98,99,101 This means that despite effective caspase inhibition, the cell is continuously 'flooded' with factors that can still provoke apoptotic morphologies and death. Two factors may be important in this process (Figure 1): (i) AIF which has recently been cloned and identified as a mitochondrial interspace membrane protein with homology to bacterial NADH oxidoreductases. ${ }^{112}$ In response to apoptotic stimuli, it is liberated, migrates to the nucleus and participates in the induction of chromatin condensation and the dissipation of the mitochondrial membrane potential (positive feedback loop) in a Z-VAD.fmk-insensitive manner. (ii) Bax and Bax-like proteins, pro-apoptotic homologs of the Bcl-2 family, which are known to form ion channels on artificial membranes and isolated mitochondria. ${ }^{67,113,114}$ Bax is both a membrane and cytoplasmic protein and there is increasing evidence that the cytoplasmic form undergoes a conformational change and translocates to mitochondrial membranes in response to apoptotic stimuli. ${ }^{115-118}$ There it may puncture the outer mitochondrial membrane releasing cytochrome c, AIF and other factors ${ }^{119,120}$ or promote the opening of the mitochondrial permeability transition (PT) pore through its association with the adenine nucleotide translocator (ANT), a crucial component of the pore. ${ }^{121}$

How AIF and other released proteins trigger the apoptotic guillotine in the absence of caspases is unknown. An attractive possibility is that they activate other proteases such as serine proteases, calpains and cathepsins which can partially take over the job of caspases but in a less efficient way (acting as 'scissors' instead of 'axes') (Figure 1). Indeed, a recent report has shown that any type of protease, when loaded into cells, can provoke apoptosis-like morphologies. ${ }^{122}$ In addition, there is a fair amount of literature implicating non-caspase proteases in apoptosis. ${ }^{123-125}$ For example, serine proteases play a crucial role in the early cleavage of chromatin into $50-300 \mathrm{~kb}$ fragments before they are digested to nucleosome-sized pieces by DFF40/CAD, ${ }^{126}$ and the former but not the latter activity may persist in the presence of Z-VAD.fmk. Another crucial serine protease is AP24 because its specific inhibition confers better protection against TNF $\alpha$ and UV-induced apoptosis than a caspase-3 inhibitor. ${ }^{127}$ Furthermore, it has been postulated that the serine protease granzyme A may mediate caspase-independent CTL/target cell lysis as serine protease but not caspase inhibitors blocked this event. ${ }^{84,128}$ Another strong candidate for a 'scissor' function in caspase-independent apoptosis are the calpains. Based on inhibitor studies, these proteases participate in apoptosis in response to hypoxia in hepatocytes, ${ }^{129}$ in neuronal degeneration ${ }^{130}$ and in irradiation and dexamethasone treatment of thymocytes. ${ }^{131}$ Since they are calcium requiring enzymes, they may be activated in response to increased cytoplasmic calcium levels, for example due to mitochondrial damages (enhanced calcium cycling) ${ }^{55,132}$ In addition, calpains are known to cleave the cytoskeletal protein fodrin upstream of caspases, which 
eventually disrupts the cytoskeletal network and allows the persistent membrane blebbing seen in caspase-independent apoptosis. ${ }^{105}$ Finally, there is a clear implication of the lysosomal protease cathepsin $D$ in apoptosis induced by interferon- $\gamma$, Fas/APO-1 and TNF $\alpha{ }^{125}$ During cell death, the enzyme is processed into a proteolytically active, single chain form and itself provokes apoptosis when overexpressed. It is however yet unknown whether its proapoptotic action is within the lysosomal/endosomal system or whether it is released into the cytoplasm. This also accounts for other lysosomal components that have recently been implicated in TNF- $\alpha$-induced apoptosis. ${ }^{133}$ Why have these proteases attracted less attention for apoptosis regulation than caspases? Perhaps several types of proteases are simultaneously activated during apoptosis, and biochemical and morphological changes in response to non-caspase inhibitors may be more difficult to detect because of the predominant contribution of caspases. It might therefore be of advantage to have an apoptotic system in which caspases are not activated at all. Our group has recently identified such a system. ${ }^{134}$

Ts20 fibroblasts containing a temperature-sensitive mutation in the ubiquitin-activating enzyme E1 die by apoptosis at the restrictive temperature because shortlived and damaged proteins accumulate due to decreased ubiquitination and degradation by the proteasome. Surprisingly, this type of cell death proceeds slowly, displays only marginal DNA condensation and cleavage, no nuclear fragmentation and is not blocked by Z-VAD.fmk. Western blot analysis and recent fluorogenic activity assays revealed that neither of the known execution caspases-3, -7 and -6 are activated at any time at the restrictive temperature. Thus, the ts20 system holds great promise to uncover molecules regulating caspase-independent apoptosis. Moreover, it may teach us more about the function of Bcl-2 because despite the absence of caspase activation, this cell survival factor blocked cell death (Figure 1). A caspase-independent death protection of $\mathrm{Bcl}-2$ has also recently been reported in cells exposed to NO. ${ }^{101}$ Perhaps Bcl-2 and homologous proteins act near a point (commitment point?) where caspase-dependent and -independent pathways bifurcate (Figure 2). Such a scenario agrees with previous reports (including our own observations) that $\mathrm{Bcl}-2$ allows clonogenic growth of rescued cells and therefore saves them better from the death fate than caspase inhibitors. ${ }^{97-99}$ Thus, while $\mathrm{Bcl}-2$ successfully interferes with the execution 'axe' and the 'scissor', caspase inhibitors cannot prevent the 'scissors' from cutting the rope.

\section{Is caspase-independent apoptosis physiological?}

Since caspase-independent apoptosis has been mainly detected in cell cultures, it is important to know whether it is physiologically relevant. Recent analysis in $C$. elegans unveiled that CED-3 is probably not the only tool that 'cuts' the rope of the guillotine. Once born with 131 surplus cells, CED-3 null worms overall look and behave normally ${ }^{9}$ and cells from these worms still die if a metabolic process required for their survival is blocked (for example in response to irradiation, toxins or lack of nutrients). ${ }^{135}$ These findings indicate that nematodal apoptosis can proceed CED-3independently, either due to the activation of redundant CED-3-like caspases such as the recently identified caspaserelated genes $c s p-1 /-2 \mathrm{~A} /-2 \mathrm{~B}^{136}$ or other proteolytic and/or degradative systems as described above. This also accounts for Drosophila flies as most embryonic cell deaths still occurred and larvae had an overall normal nervous system in the absence of the essential caspase DCP-1.22 In mammals, evidence for physiological, caspase-independent apoptosis is still murky. Weil et al have recently reported that spontaneous apoptosis of sperms does not seem to require caspases, but unfortunately this was again based on a lack of death protection by Z-VAD.fmk. ${ }^{91}$

Where do we expect to see caspase-independent apoptosis in a multicellular organism and what should it look like? Since caspase-dependent apoptosis does not only involve rapid and irreversible killing but also immediate clearing of the apoptotic cell by phagocytosis, one could search for apoptotic cells that are not efficiently engulfed. In fact, a crucial signal for engulfment is the appearance of phosphatidylserine (PS) on the cell surface, a strictly caspase-dependent process. ${ }^{137}$ In addition, we should look for apoptosis that proceeds slowly and in the absence of major nuclear fragmentation. These criteria may be fulfilled by enucleated cells such as erythrocytes or the outer layer of the epidermis. Artificially enucleated cells still show $\mathrm{Bcl}-2$ blockable, apoptotic morphologies in response to various stimuli, ${ }^{138}$ and as erythrocytes mature and lose

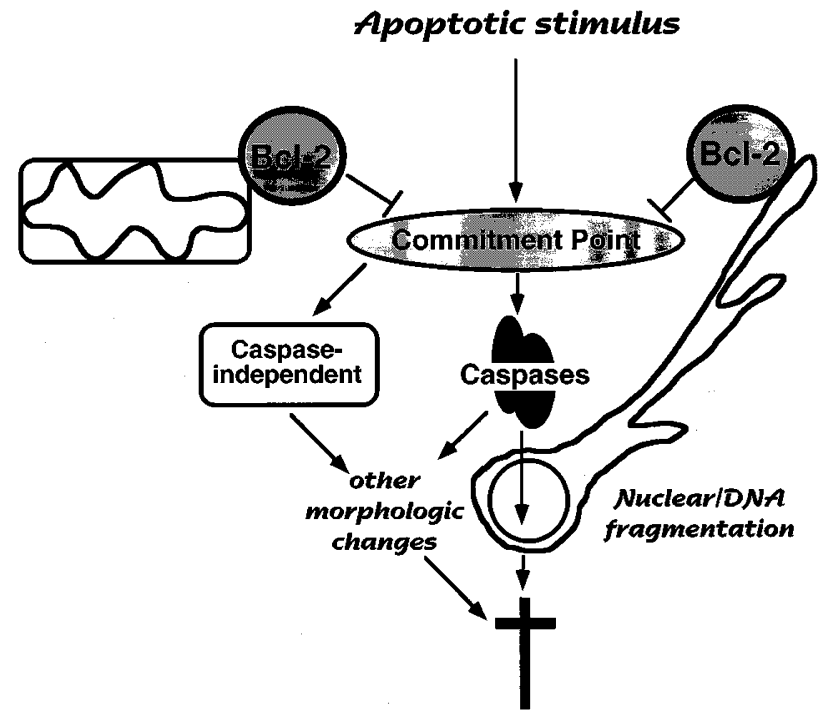

Figure $2 \mathrm{Bcl}-2$ blocks caspase-dependent and -independent apoptosis. It is proposed that $\mathrm{Bcl}-2$ acts from its site on mitochondrial and $\mathrm{ER} /$ nuclear membranes to interfere with a putative point of 'commitment' where caspasedependent and -independent signaling pathways bifurcate. By this action, Bcl2 can functionally rescue cells from both 'axe' and 'scissor' cutting actions while caspase inhibitors can only do the former. Thus, while cells rescued by $\mathrm{Bcl}-2$ are capable of clonogenic growth, those rescued by caspase inhibitors continue to die 
their nuclei, they also seem to get rid of their caspases. ${ }^{91}$ In the epidermis, some dividing basal cells move up to the granular layer where they lose their nuclei and cytoplasmic organelles and are transformed into the keratinized squames of the upper epidermal layer. These cells finally flake off from the surface of the skin. The time from the birth of a cell in the basal layer to the shedding on the surface can take 2-4 weeks. Where on this outward journey apoptosis occurs and whether it involves caspases is not known. Targeted deletion of execution caspases in the epidermis will provide us the answer.

Other attractive physiological systems of caspaseindependent apoptosis may be Huntington's and Alzheimer diseases. Jackson et al have reported a Drosophila model for Huntington's disease where transgenic baculovirus p35 was incapable of reducing the extent of neuronal degeneration. ${ }^{110}$ Similarly, although neuronal cell death during Alzheimer's disease has been proposed to involve caspase-driven apoptosis because the implicated molecules $\beta$-amyloid and presenilin 1 and 2 can be cleaved by caspases, ${ }^{139,140}$ there is no reported evidence that caspase inhibitors can interfere with disease generation or progression. Moreover, the number of degenerating neurons does not correlate with the number of cells showing TUNEL positive DNA fragmentation at any given time during the disease. ${ }^{141}$ Also, neuronal cell death in Alzheimer occurs over a lengthy period (ca. 10 years) suggesting distinct mechanisms from the classical, caspase-dependent apoptotic process (which takes $16-24 \mathrm{~h}$ to complete).

Finally, we may get mechanistic insights into caspaseindependent apoptosis from studying the process of aging. Many changes occur as an animal ages. Proteins become modified and cross-linked, somatic mutations accumulate, stress resistance decreases and the probability of death increases. ${ }^{142} \mathrm{~A}$ major reason for these changes is thought to be oxidative damage to macromolecules and lipid membranes, caused by superoxides and other free radicals that originate mainly from aerobic metabolism. ${ }^{143}$ Consistent with this notion, flies overexpressing both superoxide dismutase (SOD) and catalase (CAT), two important antioxidant enzymes, exhibited increases in life span and stress resistance. ${ }^{144}$ Similarly, a mutation in an important component of the mitochondrial electron transport, called clk-1, doubles the life span of the worm $C$. elegans, ${ }^{145}$ presumably because the metabolic rate is slowed down with an accompanying decrease in the production of oxygen radicals. Given the implication of mitochondria, oxygen radicals and DNA damage in apoptosis, ${ }^{53,54}$ it is tempting to propose that an aged cell finally succumbs to a classical way of caspase-dependent apoptosis. Several observations however speak against such a possibility. (i) the morphology of aged cells is not necessarily apoptotic, (ii) the process is slow, accumulating mistakes over the years before a cell finally dies, and (iii) worms and flies knocked out in caspases do not have an altered life span. ${ }^{8,9,22,24}$ Thus, it is more likely that aging involves components which are also used for caspaseindependent apoptosis. Again Bcl-2 may help us to identify these components as it can act as an antioxidant, ${ }^{146,147}$ and its deletion in mice leads to some phenotypes that superficially resemble aging. ${ }^{148}$

\section{Apoptosis in lower eukaryotes: genetically amenable systems to uncover caspase- independent regulators}

Lower eukaryotes such as yeast and Dictyostelium may be ideal systems to isolate components of caspase-independent apoptosis. They are both genetically amenable, their cells die with a morphology partially resembling apoptosis and at least in the case of yeast, caspases are missing from the genome. ${ }^{28,149-151}$ Dictyostelium multiplies as a unicellular organism but upon starvation aggregates and differentiates into a fungus-like sorocarp of which spores are viable and stalk cells display apoptotic morphologies except nuclear fragmentation. ${ }^{152,153}$ Based on Z-VAD.fmk inhibition experiments, stalk cell apoptosis proceeds caspase-independently although we do not know whether caspases exist in Dictyostelium. ${ }^{152}$

Yeast can be killed by various means such as oxidative stress, metabolic block, irradiation and other toxic substances, but cell death does not resemble apoptosis and there is no endogenous expression of known apoptosis regulators of the CED-3/caspase, CED-4 or Bcl-2/Bax families. Nevertheless, forced overexpression of Bax, Bak or CED-4 provokes vacuolarization and focal chromatin condensation as seen in mammalian apoptosis, ${ }^{28,150,151,154,155}$ indicating these death factors can indeed provoke a caspase-independent form of apoptosis via components that are already present in a unicellular organism. To identify these components, a mammalian expression cDNA library has recently been screened for clones that rescue yeast from Bax-mediated cell death. The search unveiled a novel Bax inhibitor (BI-1) homologous to the Testis Enhanced Gene Transcript (TEGT) that interacts with Bcl-2 (but not Bax), localizes to the ER/nuclear membrane and inhibits apoptosis in response to some but not all stimuli. ${ }^{156}$ Moreover, by using genetic complementation in a Bax-resistant yeast mutant, Matsuyama et al isolated a gene encoding a subunit of the yeast $F_{0} F_{1}$ ATPase and showed that its product was required for Baxinduced apoptosis in yeast and mammalian cells. ${ }^{157}$ As the $\mathrm{F}_{0} \mathrm{~F}_{1}$-ATPase is a mitochondrial proton pump required for aerobic respiration, it might cooperate with the channel function of Bax to transport ions and/or to release apoptogenic factors from mitochondria. Two other ER proteins appear to be attractive regulators of yeast cell death: the calnexin homologue $\mathrm{Cnx} 1$ which is necessary for yeast lethality mediated by Bak $^{154}$ and CDC48, a highly conserved ATPase with essential functions in cell division and homotypic fusion of ER vesicles whose loss of function provokes not only chromatin condensation, but strikingly also PS exposure, membrane blebbing and DNA fragmentation. ${ }^{158}$ Even $\mathrm{Bcl}-2$ can function in yeast as it improves the viability of a mutant defective in SOD1 under some growth conditions. ${ }^{147}$ This indicates that $\mathrm{Bcl}-2$ can block caspase-independent apoptosis via its antioxidant activity. Although yeast holds great promise to isolate further death regulators it remains to be seen whether they indeed make 
up an ancestral form of caspase-independent apoptosis regulation. If caspases have been only created to accelerate and/or improve the basic 'scissor' like guillotine, their reconstitution in yeast should add the 'axe' to effectively kill unicellular organisms via a full blown apoptotic morphology. Expression of caspase cascades in yeast has just been started. ${ }^{159}$

\section{Conclusions and future perspectives}

There is no doubt that multicellular organisms use a caspase 'axe' for effective cell removal by apoptosis. However, certain basic executionary processes may not necessarily require caspases and it is crucial to uncover the molecules involved. This will tell us more about ancient forms of apoptosis and probably help to understand how sperms and enucleated cells die, how epidermal surfaces shed their outer cell layer and how multicellular organisms age. It will certainly also aid in defining the function of $\mathrm{Bcl}-2$-like proteins as they seem to control both caspase-dependent and -independent pathways in a yet mysterious way. Finally, studying this cell death is important for the development of further drugs for therapeutic intervention of various apoptosis-based diseases. Although broad specificity caspase inhibitors seem to be effective against ischemia, stroke and fulminate liver disease, this may not be the case for other diseases as we cannot yet firmly say whether the dying cells are functionally rescued. If such cells would still die but slowly and without the possibility of being phagocytosed, disease progression may even be worse in the presence of caspase inhibitors.

Future research on physiological model systems of caspase-independent apoptosis, the exploitation of genetically amenable lower eukaryotes, the cloning of more caspases and the development of more general, non-toxic caspase inhibitors will all help us to face the next challenge of apoptosis research: the identification of alternative rope cutters of the cell's guillotine.

\section{Acknowledgements}

Our research is supported by the Swiss National Science Foundation and the Foundation for Ageing Research (AETAS), Geneva, Switzerland. We thank Reynald Olivier, Thierry Rossé and Sébastien Conus for critically reading the manuscript

\section{References}

1. Kerr JFR, Wyllie AH and Currie AR (1972) Apoptosis: a basic biologica phenomenon with wide-ranging implications in tissue kinetics. Br. J. Cancer 26: $239-257$

2. Wyllie AH, Kerr JFR and Currie AR (1981) Cell death: the significance of apoptosis. Int. Rev. Cytol. 68: 251-305

3. Glucksman A (1951) Cell deaths in normal vertebrate ontogeny. Biol. Rev. 26 $59-86$

4. Saunders Jr JW (1966) Death in embryonic systems. Science 154: 604-612

5. Thompson CB (1995) Apoptosis in the pathogenesis and treatment of disease. Science 267: $1456-1462$

6. Bellamy COC, Malcomson RDG, Harrison DJ and Wyllie AH (1995)Cell death in health and disease: the biology and regulation of apoptosis. Sem. Canc. Biol. 6: $3-16$

7. Jacobson MD, Weil M and Raff MC (1997) Programmed cell death in animal development. Cell 88: 347-354
8. Ellis HM and Horvitz HR (1986) Genetic control of programmed cell death in the nematode $C$. elegans. Cell 44: 817-829

9. Shaham S and Horvitz HR(1996) Developing Caenorhabditis elegans neurons may contain both cell-death protective and killer activities. Genes Dev. 10: $578-591$

10. Xue D and Horvitz HR (1995) Inhibition of the Caenorhabditis elegans celldeath protease CED-3 by a CED-3 cleavage site in baculovirus p35 protein. Nature 377: 248-251

11. Chinnaiyan AM, O'Rourke K, Lane BR and Dixit VM (1997) Interaction of CED-4 with CED-3 and CED-9: A molecular framework for cell death. Science 275: $1122-1126$

12. Seshagiri S and Miller LK (1997) Caenorhabditis elegans CED-4 stimulates CED-3 processing and CED-3-induced apoptosis. Curr. Biol. 7: 455-460

13. Chinnaiyan AM, Chaudhary D, O'Rourke K, Koonin EV and Dixit VM (1997) Role of CED-4 in the activation of CED-3. Nature 388: 728-729

14. Yang $X$, Chang $H Y$ and Baltimore D (1998) Essential role of CED-4 oligomerization in CED-3 activation and apoptosis. Science 281: 1355-1357

15. Steller $H$ (1995) Mechanisms and genes of cellular suicide. Science 267 : $1445-1449$

16. White K, Grether ME, Abrams JM, Young L, Farrell K and Steller H (1994) Genetic control of programmed cell death in Drosophila. Science 264: 677682

17. Grether ME, Abrams JM, Agapite J, White K and Steller H (1995) The head involution defective gene of Drosophila melanogaster functions in programmed cell death. Genes Dev. 9: 1694-1708

18. Chen P, Nordstrom W, Gish B and Abrams JM (1996) Grim, a novel cell death gene in Drosophila. Genes Dev. 10: 1773-1782

19. White K, Tahaoglu E and Steller H (1996) Cell killing by the Drosophila gene reaper. Science 271: $805-807$

20. Pronk GJ, Ramer K, Amiri P and Williams LT (1996) Requirement of an ICE-like protease for induction of apoptosis and ceramide generation by REAPER. Science 271: 808-812

21. Fraser AG and Evan GI (1997) Identification of a Drosophila melanogaster ICE/ CED-3-related protease, drICE. EMBO J. 16: 2805-2813

22. Song Z, McCall K and Steller H (1997) a Drosophila cell death protease essential for development. Science 275: $536-540$

23. Chen P, Rodriguez A, Erskine R, Thach T and Abrams JM (1998) Dredd, a novel effector of the apoptosis activators reaper, grim and hid in Drosophila. Dev. Biol. 201: $202-216$

24. McCall K and Steller H (1998) Requirement for DCP-1 caspase during Drosophila oogenesis. Science 279: 230-234

25. Hengartner MO, Ellis RE and Horvitz HR (1992) Caenorhabditis elegans gene ced-9 protects cells from programmed cell death. Nature 356: 494-499

26. Wu D, Wallen HD and Nunez G (1997) Interaction and regulation of subcellular localization of CED-4 by CED-9. Science 275: 1126-1129

27. Spector MS, Desnoyers S, Hoeppner DJ and Hengartner MO (1997) Interaction between the $C$. elegans cell-death regulators CED-9 and CED-4. Nature 385 : $653-656$

28. James C, Gschmeissner S, Fraser A and Evan GI (1997) CED-4 induces chromatin condensation in Schizosaccharomyces pombe and is inhibited by direct physical association with CED-9. Curr. Biol. 7: 246-252

29. Vucic D, Kaiser WJ and Miller LK (1998) Inhibitor of apoptosis proteins physically interact with and block apoptosis induced by Drosophila proteins HID and GRIM. Mol. Cell Biol. 18: 3300-3309

30. Deveraux QL, Takahashi R, Salvesen GS and Reed JC (1997) X-linked IAP is a direct inhibitor of cell-death proteases. Nature 388: 300-304

31. Nunez G, Benedict MA, Hu Y and Inohara N (1998) Caspases: the proteases of the apoptotic pathway. Oncogene 17: 3237-3245

32. Nicholson DW and Thornberry NA (1997) Caspases: killer proteases. Trends Biochem. 22: 299-306

33. Garcia-Calvo M, Peterson EP, Leiting B, Ruel R, Nicholson DW and Thornberry NA (1998) Inhibition of human caspases by peptide-based and macromolecular inhibitors. J. Biol. Chem. 273: 32608-32613

34. Kuida K, Zheng TS, Na S, Kuan C-Y, Yang D, Karasuyama H, Rakic P and Flavell RA (1996) Decreased apoptosis in the brain and premature lethality in CPP32-deficient mice. Nature 384: 368-372 
35. Woo M, Hakem R, Soengas MS, Duncan GS, Shahinian A, Kagi D, Hakem A McCurrach M, Khoo W, Kaufman SA, Senaldi G, Howard T, Lowe SW and Mak TW (1998) Essential contribution of caspase 3/CPP32 to apoptosis and its associated nuclear changes. Genes Dev. 12: 806-819

36. Patel T, Gores GJ and Kaufmann SH (1996) The role of proteases during apoptosis. FASEB J. 10: $587-597$

37. Liu X, Zou H, Slaughter C and Wang X (1997) DFF, a heterodimeric protein that functions downstream of caspase-3 to trigger DNA fragmentation during apoptosis. Cell 89: 175-184

38. Enari M, Sakahira H, Yokoyama H, Okawa K, Iwamatsu A and Nagata S (1998) A caspase-activated DNase that degrades DNA during apoptosis, and its inhibitor ICAD. Nature 391: 43-50

39. Mashima T, Naito M, Noguchi K, Miller DK, Nicholson DW and Tsuruo T (1997) Actin cleavage by CPP-32/apopain during the development of apoptosis. Oncogene 14: 1007-1012

40. Jaenicke RU, Ng P, Sprengart ML and Porter AG (1998) Caspase-3 is required for alpha-fodrin cleavage but dispensable for cleavage of other death substrates in apoptosis. J. Biol. Chem. 273: 15540-15545

41. Kothakota S, Azuma T, Reinhard C, Kippel A, Tang J, Chu K, McGarry TJ, Kirschner MW, Koths K, Kwiatkowski DJ and Williams LT (1997) Caspase-3generated fragment of gelsolin: effector of morphological change in apoptosis. Science 278: 294-298

42. Rao L, Perez D and White E (1996) Lamin proteolysis facilitates nuclear events during apoptosis. J. Cell. Biol. 135: 1441-1455

43. Muzio M, Stockwell BR, Stennicke HR, Salvesen GS and Dixit VM (1998) An induced proximity model for caspase-8 activation. J. Biol. Chem. 273: 2926 2930

44. Chou JJ, Matsuo H, Duan H and Wagner G (1998) Solution structure of the RIADD CARD and model for CARD/CARD interaction in caspase-2 and caspase-9 recruitment. Cell 94: 171-180

45. Stennicke HR, Jurgensmeier JM, Shin H, Deveraux Q, Wolf BB, Yang X, Zhou Q, Ellerby HM, Ellerby LM, Bredesen D, Green DR, Reed JC, Froelich CJ and Salvesen GS (1998) Pro-caspase-3 is a major physiologic target of caspase-8. J. Biol. Chem. 273: 27084-27090

46. Varfolomeev EE, Schuchmann M, Luria V, Chiannilkulchai N, Beckman JS, Mett IL, Rebrikov D, Brodianski VM, Kemper OC, Kollet O, Lapidot T, Soffer D, Sobe T, Avraham KB, Goncharov T, Holtmann H, Lonai P and Wallach D (1998) Targeted disruption of the mouse caspase 8 gene ablates cell death induction by TNF receptors, Fas/Apo1, and DR3 and is lethal prenatally. Immunity 9: 267-276

47. Kuida K, Haydar TF, Kuan CY, Gu Y, Taya C, Karasuyama H, Su MS, Rakic P and Flavell RA (1998) Reduced apoptosis and cytochrome c-mediated caspase activation in mice lacking caspase-9. Cell 94: 325-337

48. Hakem R, Hakem A, Duncan GS, Henderson JT, Woo M, Soengas MS, Elia A, de la Pompa JL, Kagi D, Khoo W, Potter J, Yoshida R, Kaufman SA, Lowe SW, Penninger JM and Mak TW (1998) Differential requirement for caspase 9 in apoptotic pathways in vivo. Cell 94: $339-352$

49. Zou H, Henzel WJ, Liu X, Lutschg A and Wang X (1997) Apaf-1, a human protein homologous to $\mathrm{C}$. elegans CED-4, participates in cytochrome c-dependent activation of caspase-3. Cell 90: 405-413

50. Hu Y, Ding L, Spencer DM and Nunez G (1998) WD-40 repeat region regulates Apaf-1 self-association and procaspase-9 activation. J. Biol. Chem. 273: 33489-33494

51. Srinivasula SM, Ahmad M, Fernandes-Alnemri T and Alnemri ES (1998) Autoactivation of procaspase- 9 by Apaf-1-mediated oligomerization. Mol. Cell 1: $949-957$

52. LiP, Nijhawan D, Budihardjo I, Srinivasula SM, AhmadM, Alnemri ES andWang X (1997) Cytochrome $c$ and dATP-dependent formation of Apaf-1/caspase-9 complex initiates an apoptotic protease cascade. Cell 91: 479-489

53. Kroemer G, Dallaporta B and Resch-Rigon M (1998) The mitochondrial death/ life regulator in apoptosis and necrosis. Annu. Rev. Physiol. 60: 619-642

54. Green DR and Reed JC (1998) Mitochondria and apoptosis. Science 281: 1309-1312

55. Richter C (1993) Pro-oxidants and mitochondrial $\mathrm{Ca}^{2+}$ : their relationship to apoptosis and oncogenesis. FEBS Lett. 325: 104-107

56. Liu X, Kim CN, Yang J, Jemmerson R and Wang X (1996) Induction of apoptotic program in cell-free extracts: requirement for dATP and cytochrome c. Cell 86: $147-157$
57. Kluck RM, Bossy-WetzelE, Green DR and NewmeyerDD (1997) The release of cytochrome c from mitochondria: a primary site for $\mathrm{Bcl}-2$ regulation of apoptosis. Science 275: $1132-1136$

58. Yang J, Liu X, Bhalla K, Kim CN, Ibrado AM, Cai J, Peng I-I, Jones DP and Wang $X$ (1997) Prevention of apoptosis by Bcl-2: release of cytochrome $\mathrm{C}$ from mitochondria blocked. Science 275: 1129-1132

59. Reed JC (1997) Cytochrome c: Can't live with it - can't live without it. Cell 91: $559-562$

60. Cecconi F, Alvarez-Bolado G, Meyer BI, Roth KS and Gruss P (1998) Apaf-1 (CED-4 homolog) regulates programmed cell death in mammalian development. Cell 94: 727-737

61. Yoshida H, Kong Y-Y, Yoshida R, Elia AJ, Hakem A, Hakem R, Penninger JM and Mak TW (1998) Apaf1 is required for mitochondrial pathways of apoptosis and brain development. Cell 94: 739-750

62. Hengartner MO (1998) Death cycle and Swiss army knives. Nature 391: 441 442

63. Rothe M, Pan M-G, Henzel WJ, Ayres TM and Goeddel DV (1995) The TNFR2TRAF signaling complex contains two novel proteins related to baculoviral inhibitor of apoptosis proteins. Cell 83: 1243-1252

64. Liston P, Roy N, Tamai K, Lefebvre C, Baird S, Cherton-Horvat G, Farahani R, McLean M, Ikeda J-E, MacKenzie A and Korneluk RG (1996) Suppression of apoptosis in mammalian cells by NAIP and a related family of IAP genes. Nature 379: $349-353$

65. Uren AG, Pakusch M, Hawkins CJ, Puls KL and Vaux DL (1996) Cloning and expression of apoptosis inhibitory protein homologs that function to inhibit apoptosis and/or bind tumor necrosis factor receptor-associated factors. Proc. Natl. Acad. Sci. USA 93: 4974-4978

66. Hengartner MO and Horvitz HR (1994) C. elegans cell survival gene ced-9 encodes a functional homolog of the mammalian prot-oncogene bcl-2. Cell 76: $665-676$

67. Adams JM and Cory S (1998) The Bcl-2 protein family: arbiters of cell survival. Science 281: $1322-1326$

68. Vaux DL, Weissman IL and Kim SK (1992) Prevention of programmed cell death in Caenorhabditis elegans by human bcl-2. Science 258: 1955-1957

69. Pan G, O'Rourke K and Dixit VM (1998) Caspase-9, Bcl- $x_{L}$, and Apaf-1 form a ternary complex. J. Biol. Chem. 273: 5841-5845

70. Hu Y, Benedict MA, Wu D, Inohara N and Nunez G (1998) Bcl-X $X_{L}$ interacts with Apaf-1 and inhibits Apaf-1-dependent caspase-9 activation. Proc. Natl. Acad. Sci. USA 95: 4386-4391

71. Sugimoto A, Friesen PD and Rothman JH (1994) Baculovirus p35 prevents developmentally programmed cell death and rescues a ced-9 mutant in the nematode Caenorhabditis elegans. EMBO J. 13: 2023-2028

72. Beidler DR, Tewari M, Friesen PD, Poirier GG and Dixit VM (1995) The baculovirus p35 protein inhibits Fas- and tumor necrosis factor-induced apoptosis. J. Biol. Chem. 270: 16526-16528

73. Miller LK (1997) Baculovirus interaction with host apoptotic pathways. J. Cell. Physiol. 173: 178-182

74. Fearnhead HO, Dinsdale D and Cohen GM (1995) An interleukin-1 betaconverting enzyme-like protease is a common mediator of apoptosis in thymocytes. FEBS Lett. 375: $283-288$

75. Thornberry NA, Rano TA, Peterson EP, RasperDM, Timkey T, Garcia-Calvo M, Houtzager VM, Nordstrom PA, Roy S, Vaillancourt JP, Chapman KT and Nicolson DW (1997) A combinatorial approach defines specificities of members of the caspase family and granzyme B. Functional relationships established for key mediators of apoptosis. J. Biol. Chem. 272: 17907-17911

76. Thornberry NA, Peterson EP, Zhao JJ, Howard AD, Griffin PR and Chapman KT (1994) Inactivation of interleukin-1 beta converting enzyme by peptide (acyloxy)methyl ketones. Biochemistry 33: 3934-3940

77. Hara H, Friedlander RM, Gagliardini V, Ayata C, Fink K, Huang Z, ShimizuSasamata M, Yuan J and Moskowitz MA (1997) Inhibition of interleukin 1beta converting enzyme family proteases reduces ischemic and excitotoxic neuronal damage. Proc. Natl. Acad. Sci. USA 94: 2007-2012

78. Rodriguez I, Matsuura K, Ody C, Nagata S and Vassalli P (1996) Systemic injection of a tripeptide inhibits the intracellular activation of CPP32-like proteases in vivo and fully protects mice against Fas-mediated fulminant liver destruction and death. J. Exp. Med. 184: 2067-2072 
79. Yaoita H, Ogawa K, Maehara K and Maruyama Y (1998) Attenuation of ischemia/reperfusion injury in rats by a caspase inhibitor. Circulation 97:276281

80. Lodick SA, MacKenzie A and Rothwell NJ (1996) An ICE inhibitor, z-VAD-DCB attenuates ischaemic brain damage in the rat. Neuroreport 7: 1465-1468

81. McCarthy NJ, Whyte MKB, Gilbert CS and Evan GI (1997) Inhibition of Ced-3/ ICE-related proteases does not prevent cell death induced by oncogenes, DNA damage, or the Bcl-2 homologue Bak. J. Cell Biol. 136: 215-227

82. Xiang J, Chao DT and Korsmeyer SJ (1996) Bax-induced cell death may not require interleukin 1-converting enzyme-like proteases. Proc. Natl. Acad. Sci. USA 93: $14559-14563$

83. Miller TM, Mouldner KL, Knudson CM, Creedon DJ, Deshmukh M, Korsmeyer SJ and Johnson JrEM (1997) Bax deletion further orders the cell death pathway in cerebellar granule cells and suggests a caspase-independent pathway to cell death. J. Cell Biol. 139: 205-217

84. Sarin A, Williams MS, Alexander-Miller MA, Berzofsky JA, Zacharchuk CM and HenkartPA (1997) Target cell lysis by CTL granule exocytosis is independent of ICE/Ced-3 family proteases. Immunity 6: 209-215

85. Trapani JA, Jans DA, Jans PJ, Smyth MJ, Browne KA and Sutton VR (1998) Efficient nuclear targeting of granzyme $B$ and the nuclear consequences of apoptosis induced by granzyme B and perforin are caspase-dependent, but cell death is caspase-independent. J. Biol. Chem. 273: 27934-27938

86. De Maria R, Lenti L, Malisan F, d'Agostino F, Tomassini B, Zeuner A, Rippo MR and Testi R (1997) Requirement of GD3 ganglioside in CD95- and ceramideinduced apoptosis. Science 277: 1652-1655

87. Woodle ES, Smith DM, Bluestone JA, Kirkman III WM, Green DR and Skowronski EW (1997) Anti-human class I MHC antibodies induce apoptosis by a pathway that is distinct from the Fas antigen-mediated pathway. J Immunol. 158: 2156-2164

88. Schlapbach R and Fontana A (1997) Differential activity of bcl-2 and ICE enzyme family protease inhibitors on Fas and puromycin-induced apoptosis of glioma cells. Biochem. Biophys. Acta 1359: 174-180

89. Ha HC, Woster PM and Casero Jr RA (1998) Unsymmetrically substituted polyamine analogue induces caspase-independent programmed cell death in Bcl-2-overexpressing cells. Cancer Res. 58: 2711-2714

90. Deas O, Dumont C, MacFarlane M, Rouleau M, Heibb C, Harper F, Hirsch F, Charpentier B, Cohen GM and Senik A (1998) Caspase-independent cell death induced by anti-CD2 or staurosporine in activated human peripheral $T$ lymphocytes. J. Immunol. 161: 3375-3383

91. Weil M, Jacobson MD and Raff MC (1998) Are caspases involved in the death of cells with a transcriptionally inactive nucleus? Sperms and chicken erythrocytes. J. Cell Sci. 111: 2707-2715

92. Zanke BW, Lee C, Arab S and Tannock IF (1998) Death of tumor cells after intracellular acidification is dependent on stress-activated protein kinases (SAPK/JNK) pathway activation and cannot be inhibited by bcl-2 expression or interleukin 1 beta-converting enzyme inhibition. Cancer Res. 58: 2801-2808

93. Adachi H, Adams A, Hughes FM, Zhang JD, Cidlowski JA and Jetten AM (1998) Induction of apoptosis by the novel retinoid AHPN in human T-cell lymphoma cells involves caspase-dependent and -independent pathways. Cell Death Differ. 5: 973-983

94. Lavoie JN, Nguyen M, Marcellus RC, Branton PE and Shore GC (1998) E4orf4, a novel adenovirus death factor that induces p53-independent apoptosis by a pathway that is not inhibited by zVAD-fmk. J. Cell Biol. 140: 637-645

95. Johnson MD, Xiang H, London S, Kinoshita $Y$, Knudson M, Mayberg M, Korsmeyer SJ and Morrison RS (1998) Evidence for involvement of Bax and p53, but not caspases, in radiation-induced cell death of cultured postnatal hippocampal neurons. J. Neurosci. Res. 54: 721-733

96. Park DS, Morris EJ, Stefanis L, Troy CM, Shelanski ML, Geller HM and Greene LA (1998) Multiple pathways of neuronal death induced by DNA-damaging agents, NGF deprivation, and oxidative stress. J. Neurosci. 18: 830-840

97. Amarante-Mendes GP, Finucane DM, Martin SJ, Cotter TG, Salvesen GS and Green DR (1998) Anti-apoptotic oncogenes prevent caspase-dependent and independent commitment for cell death. Cell Death Differ. 5: 298-306

98. Brunet CL, Gunby RH, Benson RSP, Hickman JA, Watson AJM and Brady G (1998) Commitment to cell death measured by loss of clonogenicity is separable from the appearance of apoptotic markers. Cell Death Differ. 5 :

99. Benson RSP, Dive C and Watson AJM (1998) Comparative effects of Bcl-2 overexpression and ZVAD.FMK treatment on dexamethasone and VP16induced apoptosis in CEM cells. Cell Death Differ. 5: 432-439
100. Quignon F, De Bels F, Koken M, Feunteun J, Ameisen JC and de The H (1998) PML induces a novel caspase-independent death process. Nat. Genet. 20: $259-265$

101. Okuno S-I, Shimizu S, Ito T, Nomura M, Hamada E, Tsujimoto Y and Matsuda H (1998) Bcl-2 prevents caspase-independent cell death. J. Biol. Chem. 273: $34272-34277$

102. Kawahara A, Ohsawa Y, Matsumura H, Uchiyama $Y$ and Nagata S (1998) Caspase-independent cell killing by Fas-associated protein with death domain. J. Cell Biol. 143: 1353-1360

103. Harada J and Sugimoto M (1998) Inhibitors of interleukin-1 beta-converting enzyme-family proteases (caspases) prevent apoptosis without affecting decreased cellular ability to reduce 3-(4,5-dimethylthiazol-2-yl)-2,5-diphenyltetrazolium bromide in cerebellar granule neurons. Brain Res. 793: 231-243

104. Ekert PG, Silke J and Vaux DL (1999) Inhibition of apoptosis and clonogenic survival of cells expressing crmA variants: optimal caspase substrates are not necessarily optimal inhibitors. EMBO J. 18: $330-338$

105. Waterhouse NJ, Finucane DM, Green DR, Elce JS, Kumar S, Alnemri ES, Litwack G, Khanna K, Lavin MF and Watters DJ (1998) Calpain activation is upstream of caspases in radiation-induced apoptosis. Cell Death Differ. 5: $1051-1061$

106. Schotte P, Declercq W, Van Huffel S, Vandenabeele P and Beyaert R (1998) Non-specific effects of methyl ketone peptide inhibitors of caspases. FEBS Lett. 442: $117-121$

107. Davidson FF and Steller H (1998) Blocking apoptosis prevents blindness in Drosophila retinal degeneration mutants. Nature 391: 587-591

108. Bump NJ, Hackett M, Hugunin M, Seshagriri S, Brady K, Chen P, Ferenz C, Franklin S, Ghayur T, Licari LPP, Mankovich J, Shi L, Greenberg AH, Miller LK and Wong WW (1995) Inhibition of the ICE family proteases by baculovirus antiapoptotic protein p35. Science 269: 1885-1888

109. Zhou Q, Krebs JF, Snipas SJ, Price A, Alnemri ES, Tomaselli KJ and Salvesen GS (1998) Interaction of the baculovirus anti-apoptotic protein p35 with caspases. Specificity, kinetics, and characterization of the caspase/p35 complex. Biochemistry 37: 10757-10765

110. Jackson GR, Salecker I, Dong X, YaoX, Arnheim N, Faber PW, MacDonald ME and Zipursky SL (1998) Polyglutamine-expanded human huntingtin transgenes induce degeneration of Drosophila photoreceptor neurons. Neuron 21: 633-642

111. Bose R, Chen P, Loconti A, Grulich C, Abrams JM and Kolesnick RN (1998) Ceramide production by the reaper protein is not blocked by the caspase inhibitor, p35. J. Biol. Chem. 273: 28852-28859

112. Susin SA, Lorenzo HK, Zamzami N, Marzo I, Snow BE, Brothers GM, Mangion J, Jacotot E, Costantini P, Loeffler M, Larochette N, Goodlett DR, Aebersold R, Siderovski DP, Penninger JM and Kroemer G (1999) Molecular characterization of mitochondrial apoptosis-inducing factor. Nature 397: 441-446

113. Silke J and Vaux DL (1998) Cell death: Shadow Baxing. Curr. Biol. 8: R528R531

114. Schendel SL, Montal M and Reed JC (1998) Bcl-2 family proteins as ionchannels. Cell Death Differ. 5: 372-380

115. Hsu Y-T, Wolter KG and Youle RJ (1997) Cytosol-to-membrane redistribution of Bax and $B c l-x_{L}$ during apoptosis. Proc. Natl. Acad. Sci. USA 94: 3668-3672

116. Wolter KG, Hsu Y-T, Smith CL, Nechushtan A, Xi X-G and Youle RJ (1997) Movement of Bax from the cytosol to mitochondria during apoptosis. J. Cell Biol. 139: $1281-1292$

117. Gross A, Jockel J, Wei MC and Korsmeyer SJ (1998) Enforced dimerization of $B A X$ results in its translocation, mitochondrial dysfunction and apoptosis. EMBO J. 17: 3878-3885

118. Goping IS, Gross A, Lavoie JN, Nguyen M, Jemmerson R, Roth K, Korsmeyer SJ and Shore GC (1998) Regulated targeting of BAX to mitochondria. J. Cell Biol. 143: 207-215

119. Juergensmeier JM, Xie Z, Deveraux Q, Ellerby L, Bredesen D and Reed JC (1998) Bax directly induces release of cytochrome $c$ from isolated mitochondria. Proc. Natl. Acad. Sci. USA 95: 4997-5002

120. Rosse T, Olivier R, Monney L, Rager M, Conus S, Fellay I, Jansen B and Borner C (1998) Bcl-2 prolongs cell survival after Bax-induced release of cytochrome c. Nature 391: 496-499

121. Marzo I, Brenner C, Zamzami N, Juergensmeier JM, Susin SA, Vieira HLA, Prevost M-C, Xie Z, Matsuyama S, Reed JC and Kroemer G (1998) Bax and adenine nucleotide translocator cooperate in the mitochondrial control of apoptosis. Science 281: 2027-2031 
122. Williams MS and Henkart PA (1994) Apoptotic cell death induced by intracellular proteolysis. J. Immunol. 153: 4247-4255

123. Hughes Jr FM and Cidlowski JA (1996) The Enzymology of Apoptosis. In: Apoptosis in Normal Development and Cancer, M Sluyser, ed. (Bristol, PA: Taylor and Francis, Ltd.), p. 21-38

124. Squier MKT and Cohen JJ (1996) Calpain and cell death. Cell Death Differ. 3 : $275-283$

125. Deiss LP, Galinka H, Berissi H, Cohen O and Kimchi A (1996) Cathepsin D protease mediates programmed cell death induced by interferon-, Fas/APO-1 and TNF-alpha. EMBO J. 15: $3861-3870$

126. Hughes Jr FM, Evans-Storms RB and Cidlowski JA (1998) Evidence that noncaspase proteases are required for chromatin degradation during apoptosis. Cell Death Differ. 5: 1017-1027

127. Wright SC, Schellenberger U, Wang H, Kinder SH, Talhouk JW and Larrick JW (1997) Activation of CPP32-like proteases is not sufficient to trigger apoptosis: inhibition of apoptosis by agents that suppress activation of AP24, but not CPP32-like activity. J. Exp. Med. 186: 1107-1117

128. Chang TW and Eisen HE (1980) Effects of N-tosyl-L-lysyl-chloromethylketone on the activity of cytolytic T lymphocytes. J. Immunol. 124: 1028-1033

129. Bronk SF and Gores GJ (1993) pH-dependent nonlysosomal proteolysis contributes to lethal anoxic injury of rat hepatocytes. Am. J. Physiol. 264: G744-G751

130. Saito K, Elce JS, Hamos JE and Nixon RA (1993) Widespread activation of calcium-activated neutral proteinase (calpain) in the brain in Alzheimer disease: a potential molecular basis for neuronal degeneration. Proc. Natl. Acad. Sci. USA 90: 2628-2632

131. Squier MKT, Miller ACK, Malkinson AM and Cohen J (1994) Calpain activation in apoptosis. J. Cell Physiol. 159: 229-237

132. Berridge MJ, Bootman MD and Lipp P (1998) Calcium - a life and death signal. Nature 395: $645-648$

133. Monney L, Olivier R, Otter I, Jansen B, Poirier GG and Borner C (1998) Role of an acidic compartment in tumor-necrosis-factor-alpha-induced production of ceramide, activation of caspase-3 and apoptosis. Eur. J. Biochem. 251: 295 303

134. Monney L, Otter I, Olivier R, Ozer HL, Haas AL, Omura S and Borner C (1998) Defects in the ubiquitin pathway induce caspase-independent apoptosis blocked by Bcl-2. J. Biol. Chem. 273: 6121-6131

135. Hall DH, Gu GQ, Garciaanoveros J, Gong L, Chalfie M and Driscoll M (1997) Neuropathology of degenerative cell death in Caenorhabditis elegans. J. Neurosci. 17: 1033-1045

136. Shaham S (1998) Identification of multiple Caenorhabditis elegans caspases and their potential roles in proteolytic cascades. J. Biol. Chem. 273: 35109 35117

137. Martin SJ, Finucane DM, Amarante-Mendes GP, O'Brien GA and Green DR (1996) Phosphatidylserine externalization during CD95-induced apoptosis of cells and cytoplasts requires ICE/CED-3 protease activity. J. Biol. Chem. 271: 28753-28756

138. Jacobson MD, Burner JF and Raff MC (1994) Programmed cell death and Bcl-2 protection in the absence of a nucleus. EMBO J. 13: 1899-1910

139. Barnes NY, Li L, Yoshikawa K, Schwartz LM, Oppenheim RW and Milligan CE (1998) Increased production of amylois precursor protein provides a substrate for caspase-3 in dying motorneurons. J. Neruosci. 18: 5869-5880
140. Tanzi RE (1998) Of calcium, caspases, and cognitive decline. Nat. Med. 4 : $1127-1128$

141. Perry $G$ and Nunomura A (1998) Apoptosis and Alzheimer's disease. Science 282: 1268

142. WoodWB (1998) Aging of C. elegans: Mosaicsand Mechanisms. Cell 95: 147 150

143. Johnson FB, Sinclair DA and Guarente L (1999) Molecular Biology of Aging. Cell 96: 291-302

144. Orr WC and Sohal RS (1994) Extension of life-span by overexpression of superoxide dismutase and catalase in Drosophila melanogaster. Science 263: $1128-1130$

145. Ewbank JJ, Barnes TM, Lakowski B, Lussier M, Bussey H and Hekimi S (1997) Structural and functional conservation of the Caenorhabditis elegans timing gene clk-1. Science 275: 980-983

146. Hockenbery DM, Oltvai ZN, Yin X-M, Milliman CL and Korsmeyer SJ (1993) Bcl2 functions in an antioxidant pathway to prevent apoptosis. Cell 75: 241-251

147. Kane DJ, Sarafin TA, Auton S, Hahn H, Gralla FB, Valentine JC, Ord T and Bredesen DE (1993) Bcl-2 inhibition of neural cell death: decreased generation of reactive oxygen species. Science 262: 1274-1276

148. Veis DJ, Sorenson CM, Shutter JR and Korsmeyer SJ (1993) Bcl-2-deficien mice demonstrate fulminant lymphoid apoptosis, polycystic kidneys, and hypopigmented hair. Cell 75: 220-340

149. Olie RA, Durrieu F, Cornillon S, Loughran G, Gross J, Earnshaw WC and Golstein P (1998) Apparent caspase independence of programmed cell death in Dictyostelium. Curr. Biol. 8: 955-958

150. Ink B, Zoernig M, Baum B, Hjibagheri N, James C, Chittenden T and Evan G (1997) Human Bak induces cell death in Schizosaccharomyces pombe with morphological changes similar to those with apoptosis in mammalian cells. Mol. Cell. Biol. 17: 2468-2474

151. ZhaH, FishHA, Yaffe MP, Mahajan N, Herman B and Reed JC (1996) Structurefunction comparisons of the proapoptotic protein Bax in yeast and mammalian cells. Mol. Cell Biol. 16: 6494-6508

152. Raper KB (1984) The Dictyostelids, Princeton University press Princeton

153. Cornillon S, Foa C, Davoust J, Buonavista N, Gross JD and Golstein P (1994) Programmed cell death in Dictyostelium. J. Cell. Sci. 107: 2691-2704

154. Torgler CN, de Tiani M, Raven T, Aubry J-P, Brown R and Meldrum E (1997) Expression of bak in S. pombe results in a lethality mediated through interaction with the calnexin homologue $\mathrm{Cnx1}$. Cell Death Differ. 4: 263-271

155. Juergensmeier JM, Krajewski S, Armstrong R, Wilson GM, Oltersdorf T, Fritz LC, Reed JC and Ottilie S (1997) Bax- and Bak-induced cell death in the fission yeast Schizosaccharomyces pombe. Mol. Biol. Cell 8: 325-329

156. Xu Q and Reed JC (1998) Bax inhibitor-1, a mammalian apoptosis suppressor identified by functional screening in yeast. Mol. Cell 1: 337-346

157. Matsuyama S, Xu Q, Velours J and Reed JC (1998) The mitochondrial $F_{0} F_{1}$. ATPase proton pump is required for function of the proapoptotic protein Bax in yeast and mammalian cells. Mol. Cell 1: $327-336$

158. Madeo F, Froehlich E and Froehlich KU (1997) A yeast mutant showing diagnostic markers of early and late apoptosis. J. Cell Biol. 139: 729-734

159. Kang JJ, Schaber MD, Srinivasula SM, Alnemri ES, Litwack G, Hall DJ and Bjornsti MA (1999) Cascades of mammalian caspase activation in the yeast Saccharomyces cerevisiae. J. Biol. Chem. 274: 3189-3198 